\title{
REGEERINGSMAATREGELEN TEN BEHOEVE VAN DEN LANDBOUW IN BELGIE.
}

Het is cen opmerkelijk verschijnsel, dat, in den laatsten tijd, in bijna alle landen van Regeeringswege veel meer aandacht wordt geschonken aan de belangen van den landbouw, dan voor weinig jaren het geval was.

Bij ons te lande heeft het langer dan elders geduurd, alvorens Regeering en Vertegenwoordiging, de overtuiging erlangden, dat die tak van nijverheid behoefte hat aan steun en voorlichting van Staatswege. Mogelijk vindt dit verschijnsel daarin zijne verklaring, dat tot voor korten tijd het ontwikkelde publiek in ons land zoo weinig vertrouwd was met de eigenlijke belangen van het landbouwersbedrijf. Men zal toch moeielijk een ander land kumnen aanwijzen waar, onder de ontwikkelde standen, zoo weinig gezonde begrippen aangaande dezen tak van bedrijf worden aangetroffen.

Langen tijd werden de landbouwbelangen in Regeeringskringen dan ook verwarloosd. Sedert eenige jaren is daarin echter eene aanmerkelijke wijziging ten goede gekomen. Wanneer de uitdrukking niet eenigszins banaal klonk, zou men kunnen beweren dat de landbouw tegenwoordig in de mode is en ook in ons Parlement vinden ontwerpen, die daarmede in verband staan bij zoo goed als alle partijen een gunstig onthaal.

Vooral het tot stand komen der Staatscommissie voor den Landbouw mag als een zeer verblijdend verschijnsel worden begroet. De wijze waarop die Commissie haar taak heeft aangevangen mag met grond doen verwacliten 
dat door haar toedoen veel wat tot heden op dit gebied ongerlaan bleef op flinke wijze zal worden ter hand genomen.

Het kan mogelijk zijn nut hebben eens na te gaan, welke maatregelen er in andere landen genomen zijn om den kwijnenden landbouw te hulp te komen. Voor heden wensch ik mij te bepalen tot België, wijl het mij toeschijnt dat daar de zaak op uiterst praktische en doeltreffende wijze is aangevat en dat het aanbeveling zou verdienen om dienzelfden weg bij ons te lande inteslaan.

Bij Kon. besluit van 26 September 1885 werd vastgesteld, dat naast het Departement van Landbouw, Nijverheid en Waterstaat een corns van negen Rijkslandhuishoudkundigen zou worden opgericht, waarvan rle benoeming door den Koning geschiedt. Het salaris van deze ambtenaren werd vastgesteld op 3500-4500 firs. Alleen zij die in het bezit waren van bet diploma van ingenieur agricole konden voor eene benoeming in aanmerking komen. Van dezen regel kan echter afgeweken worden voor die landbouwkundigen, die zich door lijzondere verdiensten hebben onderscheiden.

Deze Agronomes de l'Etat (zooals hun titel luidt) hebben in opdracht om de wetenschappelijke begrippen op landbouwgebied zooveel mogelijk onder het berelk te brengen van belanghebbenden. Zij moeten door veelvuldigen omgang het vertrouwen der boeren zien te winnen en zijn verplicht om op verzoek kosteloos adviezen te verstrekken. Zij zijn tevens ommegaande leeraars in hun district en richten hunne voordrachten zoodanig in dat minstens op vijf verschillende plaatsen in iedere Provincie een volledige cursus wordt gehouden over een of ander onderdeel van den landbouw of aanverwante vakken, waarvan de kennis voor de boeren van belang kan worden geacht.

In ieder district worden proefvelden aangelegd, die 
onder toezicht staan dezer ambtenaren en welke ten doel hebben om door aanschouwing gestalte te geven aan datgene wat door woord en schrift is aanbevolen.

De Inspecteur van den Landbouw is de directe chef van dit college. Hij regelt de bezigheden van ieder in het bijzonder en verstrekt de noodige instructies. De uitkomsten verkregen met de verschillende proefnemingen worden in een bundel vereenigd en zooveel mogelijk verspreid. De standplaats der verschillende Staatslandbouwkundigen is als volgt: Oostvlaanderen, Westvlaanderen, de Kempen, Braband, Limon, Condroz en de Ardennen.

Het besluit waarbij tot oprichting der proefvelden werd overgegaan luidt als volgt:

Art. 1. Er zullen worden opgericht proefvelden of velden van onderzoek, welke bestemd zijn om tot aanschouwelijk onderricht te dienen voor de landbouwer's in een bepaalde streek. In iedere Provincie zullen er ten minste vijf worden aangelegd.

Art. 2. De Minister van Landbouw enz. stelt het cultuurplan vast en bepaalt het doel dat met de onderzoekingen en proefcultures moet worden beoogd.

De werkzaamheden worden uitgevoerd door landbouwers, welke aanvraag gedaan hebben om op hunne gronden proefcultures uittevoeren, onder toezicht en volgens de aanwijzingen van den betrokken Staatslandbouwkundige.

De aanvragen tot het mogen aanleggen van zulke proefvelden geschieden aan den Minister van Landbouw enz. Het terrein, de stalmest en de noodige arbeidskrachten moeten door de aanvragers kosteloos ter beschikking worden gesteld van den Staat, gedurende den geheelen duur van de proefnemingen.

Het verslag dat door de Regeering jaarlijks wordt uitgebracht verschijnt in het Bulletin de l'Agriculture, 
welk orgaan bij Kon. besluit dd. 16 Juli 1885 werd ingesteld. Het is een tijdschrift dat voor een geringen prijs (3.75 frs. jaarlijks) van wege het Ministerie van Landbouw wordt uitgegeven.

Tal van bekende landbouwkundigen verleenen hunne medewerking, terwijl bovendien alle officieele stukken welke op landbouw betrekking hebben $\mathrm{er}^{\mathrm{r}}$ in worden opgenomen. In een afzonderlijk nummer verschijnen dw verschillende verslagen over de Proefvelden, welke over geheel Belgie zijn verspreid.

Naast dit Tijdschrift, dat meer voor het groote publiek bestemd is, wordt bovendien een geheel officieel orgaan door de Belgische Regeering uitgegeven, getiteld: Bulletin du Conseil Supérieur de l'Agriculture. Dit geschrift bevat de notulen van de vergaderingen van dit college en is niet in den handel verkrijgbaar.

Op dit oogenblik zijn er drie jaargangen van het Bulletin de l'Agriculture verschenen. die ierler een dik boekdeel nitmaken. Dit geheel vormt een zeer leerzame en lezenswaardige lektuur en is er op berekend om in wijden kring nut te verspreiden. De verslagen over de proefvelden en de proefcultures vormen voorzeker niet het minst belangrijke gedeelte van het werk. Het doel daarmede beoogd is niet zoozeer het doen van nieuwe wetenschappelijke onderzoekingen dan wel om aan de boeren een voorbeeld onder de oogen te brengen van rationeele cultuur, dat hen tot navolging zal prikkelen.

$\mathrm{Nu}$ eens zullen het nieuwe varieteiten van landbouwgewassen zijn, welke zich door hooge opbrengst onderscheiden; dan weder zal de voortreffelijke werking aangetoond worden van ver'schillende hulpmeststoffen wanneer zij op oordeelkundige wijze worden aangewend.

Wanneer men zich nu voorstelt dat op tal van plaatsen in rle Provincie dezelfde proet, volgens een zelfde methode door tal van landbouwers genomen wordt, dan kan 
men zich gemakkelijk voorstellen hoezeer daardoor de verspreiding en de kennis dier methode worden in de hand gewerkt. Dit doel wordt ook nog bevorderd door de cursussen welke door de Staatslandbouwkundigen, gedurende de wintermaanden, worden gehouden in de verschillende districten en waarin het doel, dat men. zich met deze proefnemingen voor oogen stelt, vooraf rluidelijk worden uiteengezet.

De onderzoekingen gedurende het eerste jaar bepaalden zich uitsluitend tot den beetwortel.

De beetwortelsuikerfabricage vertegenwoordigt in Belgie een allerbelangrijksten tak van nijverheid. Evenals in Duitschland kan de teelt van de suikerbiet op den daartoe geschikten grond, als de spil beschouwd worden waarom heen de vruchtwisseling in de groote cultuur draait.

Langzamerhand was deze industrie in een kwijnenden toestand geraakt, zoo zelfs dat aan de mededinging van het buitenland, hoofdzakelijk van Duitschland, niet meer het hoofd kon worden geboden. Deze critieke toestand blijkt genoegzaam uit de omstandigheid dat in 1885 van de honderdvijftig beetwortelsuikerfabrieken in Belgic, el ruim een derde hadden opgehouden te werken.

De hoofdoorzaak van dezen ongunstigen toestand was te wijten aan de mindere deugdelijkheid van de grondstof. Bij den beetwortel hangt het suikergehalte geheel af van de soort van zaad dat men bezigt en van den aard der bemesting die wordt toegepast.

In Duitschland, hoofdzakelijk in het koninkrijk Saksen en in de Pruisische provincie van dien naam, waar de landbouw zoo voorbeeldig wordt gedreven, was men door rationeele cultuur er in geslaagd om een product te teelen, dat de industrie in staat stelde om de buitenlandsche mededingers geheel te overvleugelen. Dit doel was bereikt door het uitzaaien van zaad van bieten van een buitengewoon hoog suikergehalte en loor het gebruik van doelmatige minerale meststoffen. 
Het Belgische gouvernement ontbood zaad uit Duitschland en stelde dit kosteloos ter beschikking van die landbouwers, welke zich voor het nemen van proeven hadden aangeboden. De minerale hulpbemesting werd eveneens gratis door den Staat afgestaan, terwijl de stalmest en de handenarbeid door den landbouwer moest worden geleverd, die trouwens de vrije beschikking had over den oogst.

Te zelfder tijd was de teelt van den beetwortel het onderwerp van alle landbouwlezingen, die in geheel Belgie werden gehouden.

In een tachtigtal gemeenten kwamen zulke proefvelden tot stand en de uitkomst van dit eerste jaar mag als zeer bevredigend worden beschouwd.

Het bleek toch daaruit, dat op alle gronden, die voor den teelt van den beetwortel geschikt zijn, een product te verkrijgen is met een gehalte aan suiker van 12-13 pCt. Van hoeveel gewicht deze uitkomst is, kan men gemakkelijk nagaan als men weet dat op dat tijdstip in verscheiden districten slechts beetwortels werden geleverd met een gehalte van 8 à 9 pCt. suiker, welke als grondstof voor de fabriek zoo weinig waarde hebben dat dit de hoofdoorzaak was dat zoovele fabrieken den arbeid hadden gestaakt.

Het is niet te verwonderen dat deze aanvankelijk zoo goede uitslag in hooge mate de aandacht van belanghebbenden vestigde op de maatregelen door den Staat genomen. In het volgend jaar kwamen dan ook reeds uit een zeshonderdtal gemeenten aanvragen tot het mogen uitvoeren van proefcultures.

Dit tweede jaar, warvan de uitkomsten in den loop van het jaar 1887 werden publiek gemaakt, leverde naar het mij toeschijnt minder positieve uitkomsten dan het eerste jaar.

Eensdeels werden de proefcultures dienstbaar gemaakt aan het beproeven van verschillende mestsoorten; anderEcon. 1888. 
deels werden tal van nieuwe verscheidenheden van granen, en van knolgewassen geteeld, om de opbrengst daarvan te vergelijken met de in gebruik zijnde varieteiten.

Zoo werden b.v. in Westvlaanderen, waar de cultures geleid worden door onzen vroegeren landgenoot M. Marlet, 69 proeven genomen en wel:

Onderzoekingen om door het gebruik van enkelvoudige meststoffen, de samenstelling van den grond te leeren kennen . . . . . . . . . . . . . . . . . 6

Onilerzoek naar de beste soort van haver . . . . 22

\begin{tabular}{|c|c|c|c|c|c|c|c|c|}
\hline ") & ) & ) & ) & ) & ) & tarwe & . & . \\
\hline 》 & ) & ) & 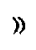 & $》$ & ) & zomergerst & . & . \\
\hline$)$ & ) & ) & ) & ) & 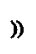 & aardappelen & . & . \\
\hline$)$ & ) & ) & $\eta$ & ) & ) & erwten. . & . & . \\
\hline ). & ) & $\eta$ & $\eta$ & ) & 》 & vlas. & . & . \\
\hline ) & ) & ) & b) & ) & ) & chicorei & . & . \\
\hline$)$ & ) & ) & ) & ) & 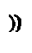 & tabak. . & . & . \\
\hline 》 & $\eta$ & ) & ) & $》$ & ) & voederworte & & \\
\hline ) & ) & )) & ) & ) & ) & beetwortels & & . \\
\hline ) & $\eta$ & ) & ) & ) & ) & mangelwort & Is & \\
\hline 》) & ) & ) & D) & ) & ) & knollen . & . & . \\
\hline$)$ & ) & ) & ) & $n$ & ) & graanmais & & $\cdot$ \\
\hline$)$ & ) & ) & ) & 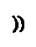 & & unstmatige $\mathrm{x}$ & yeid & en \\
\hline
\end{tabular}

Het knmt mij voor lat men zich dit tweede jaar eenigsrins op een verkeerden weg heeft begeven, door de krachten te veel te versnipperen.

Men moest zich, naar het mij voorkomt, ieder jaar bepalen tot het nemen van eenige weinige proeven, doch die op het-grootst mogelijk aantal plaatsen herhaald werden, evenals zulks het eerste jaar met de beproevingen met beetwortels is geschied.

Men heeft in België trouwens dit bezwaar zeer goed gevoeld en in 1887 heeft men dan ook zich de ervaring van het vorige jaar ten nutte gemaakt.

Het knmt mij voor dat men moeielijk een praktischer 
middel zal kunnen vinden om den landbouw te verheffen, dan door de maatregelen natevolgen welke door de Belgische Regeering genomen zijn.

Door de aanstelling van gediplomeerde landbouwkundigen van Rijkswege; zou men bij ons te lande een veel betere regeling kunnen verkrijgen van de landbouwvoordrachten dan nu het geval is.

Wil iemand toch met nut onder een landbouwende bevolking werkzaam zijn, dan moet men zich in de eerste plaats met plaatselijke toestanden bekend maken. Hoe vaak komt het nu niet voor dat wandelleeraars, ten gevolge van gebrek aan lokale kennis, onderwerpen bespreken, die voor een bepaalde streek van geen belang zijn.

Is echter aan den deskundige een bepaalde kring aangewezen, dan zal hij zich grondig met de daar bestaande toestanden kunnen bekend maken en wanneer hij aan de kennis de noodige tact paart, dan zijn alle gegevens voorhanden om een invloed ten goede te kunnen uitoefenen.

Het zal dan tevens niet moeielijk vallen om een goede regeling te treffen aangaande het geven van voortgezet landbouwonderwijs. Er kunnen wintercursussen worden gehouden, die, zon zij gegeven worden zooals zulks beloort, zeer zeker in hooge mate de belangstelling zullen wekken van ben die el' behoefte aan hebben.

Door het instellen van proefvelden over aanschouwelijk onderwijs en het doen uitvoeren van juist omschreven proefcultures door de landbouwers zelven, zal men een machtig middel bezitten om de roordeelen, welke de rationeele cultuur aanbiedt, onder de oogen te brengen van het landbouwend publiek.

En eindelijk zal men door de uitgave van een tijdschrift in den geest van het Bulletin de l'Agriculture een vakorgaan verkrijgen waarvan de verschijning loor de ontwikkelde landbouwers zeker met belangstelling zal worden begroet. 
De tijd waarin men mocht klagen dat er bij ons te lande niets vool den landbouw geschiedde is gelukkig voorbij. Integendeel, zoowel bij de Regeering als bij de Volksvertegenwoordiging is het begrip doorgedrongen dat deze z.oo belangrijke tak van volksbestaan recht heeft op meer belangstelling, dan zij tot voor weinig jaren mocht genieten.

Dit geeft dan ook moed voor de toekomst. De voorstellen van de Staatscommissie voor den Landbouw hebben rceds aanvankelijk zulk een gunstig onthaal gevonden in de Regeeringskringen dat wij met recht mogen verwachten dat ook voor het vervolg hare adviezen krachtigen invloed zullen uitoefenen op den Wetgevenden arbeid op dit gebied. En mocht op voorstel van deze Commissie eene organisatie worden in het leven geroepen zooals zij in Belgie bestaat en welke in bovenstaande regelen is geschetst dan houden wij ons overtuigd dat aan den Vaderlandschen Landbouw een groote dienst zou zi.jn bewezen.

Frederilisoord, Maart. F. B. LöHNis.

\section{NASCHRIFT.}

Sedert het schrijven van bovenstaande is het zeer belangrijke Rapport van de Staatscommissie in zake Landbouwonderwijs verschenen en. wordt daarin op vele punten voldaan aan de door mij geuitte desiderata. 